\title{
Toxic environment and obesity pandemia: Is there a relationship?
}

\author{
Giuseppe Latini ${ }^{1,2^{*}}$, Francesco Gallo ${ }^{3}$, Lorenzo lughetti ${ }^{4}$
}

\begin{abstract}
Obesity is a multi-factorial disease, resulting from genes, environment and behaviour interactions, and represents the most common metabolic disorder in the Western Hemisphere. Its prevalence has dramatically risen during the last three decades, reaching worldwide epidemic proportions. Recent cumulating evidence suggests that obesity may represent an adverse health consequence of exposure during the critical developmental windows to environmental chemicals disrupting endocrine function. Moreover, exposure to these chemicals seems to play a key role in the development of obesity-related metabolic and cardiovascular diseases. Further research is needed to elucidate the relationship between this exposure and the obesity pandemia and the involved mechanisms as well as to refine hazard identification.
\end{abstract}

\section{Introduction}

Obesity has recently become of great interest, due to a significant increase of this pathology during the last three decades both in children and adults. In fact, obesity represents the most common metabolic disorder in the Western industrialized countries, even if it is reaching worldwide epidemic proportions involving also developing countries [1-4]. In addition, obesity is the major risk factor for the development of insulin resistance, believed to be an important link between obesity and the associated metabolic syndrome diseases, known to reduce quality and length of life and increase medical costs [5].

Since obesity is associated with sedentary lifestyle patterns and inadequate dieting behaviours, obesity has been thought to be explained by a prolonged positive energy balance. However, this idea is now being challenged, as several social, economic and environmental factors have been shown to influence human physical growth and development, and obesity is one of the many diseases shown to have a developmental origin. In particular, obesity may be increasing as a function of developmental nutrition and exposure to environmental chemicals during the critical early life period. These compounds interfere with the body's adipose tissue biology and interact with hormone receptors. They mimic or antagonize the actions of endogenous hormones, thus

\footnotetext{
* Correspondence: gilatini@tin.it

'Division of Neonatology, Perrino Hospital, Brindisi, Italy
}

disrupting the programming of endocrine signalling pathways during critical windows of early development and differentiation. As a consequence, they are commonly defined as endocrine disrupting chemicals (EDC). Infants and children may be considered a highly susceptible population to EDC exposures [6-13]. At this regard, it should be underlined that the adipose tissue is an important endocrine tissue secreting obesity/ diabetes-related hormones and cytokines [14]. Developmental exposure to EDC can create abnormalities within the homeostatic control systems required to maintain a normal body weight throughout life [15]. In addition, recent evidence suggests that EDC may alter mechanisms involved in weight homeostasis, with consequent weight gain by increased volume of adipose tissue [16]. Moreover, lipophilic environmental pollutants, including persistent organic pollutants (POPs), pesticides, polychlorinated biphenyls (PCBs) and polybrominated diphenyl ethers (PBDEs) have been shown to accumulate in adipose tissue after exposure. On the other hand, increased adipose tissue results in altered storage of lipophilic toxicants, that may disregulate the cytochromes $\mathrm{p} 450$ gene expression profile in rat white adipose tissue $[14,17]$.

Finally, it has been hypothesized that not only environmental toxicants can modulate the genes expression, but can also produce epigenetic effects, affecting in an inheritable manner the metabolic status in humans $[18,19]$. 


\section{Discussion}

Since the discover of hormone synthesis capacity, the adipose tissue has conquered a central role in the complex system of metabolism, hunger regulation, immunity responses and fertility [20]. In fact, the adypocite produces the adipose derived hormones: leptin $[21,22]$ and adiponectin $[22,23]$, playing a key role in regulating energy balance, while the adipocytokines (resistin, chemerin, visfatin, interleukin-6, plasminogen activator inhibitor-1, retinol binding protein 4 and tumor necrosis factor alpha, angiotensin) are also immunomodulating agents [24]; anyway, all these substances are implicated in developing metabolic syndrome [25]. Last, but not least, in the fat tissue estradiol derives from aromatase activity on testosterone [26]. Adipose cells bioactivity is under the control of both hormonal (insulin, cortisol) and nervous inputs (efferent vagus), and the tissue differentiation too has been influenced by genes and their transcriptional factors (peroxisome proliferator-activated receptor $\gamma$ ) and different signals, pro and anti-differentiation, which are provided by locally produced growth factors, cytokines, and circulating hormones (insulin, insuline-like growth factor 1 - IGF1, growth hormone $\mathrm{GH}$, thyroid hormones, glucocorticoids) [27,28].

Recently chemicals have been identified as one of the environmental factors that may affect obesity and associated diseases [29]. In particular, exposure to Bisphenol A (BPA), one of the chemicals that we incidentally intake, during the critical early life time period has been reported to determine the development of obesity and hyperlipidemia. More specifically, BPA has been shown to affect the glucose transport in adipocytes and at environmentally relevant doses to inhibit the release of a key adipokine that protects humans from metabolic syndrome [29-31].

In addition, several interesting associations between different phthalate metabolites and obesity outcomes have been reported [32]. These adverse human health effects seem to be related to an interaction of these chemicals with peroxisome proliferator-activated receptors (PPARs), members of the nuclear receptor superfamily [33]. Moreover, tributyltin (TBT) has been suggested to be one of the environmental chemicals that lead to excessive accumulation of adipose tissue [34].

In particular, exposure to EDC during critical periods of development may result in adverse health effects that may not be apparent until much later in life, including obesity and diabetes [12].

More specifically, prenatal exposure to the dichlorodiphenyl-dichloroethylene (DDE) seems to be able to contribute to the obesity epidemic in women [35] and reduced growth in early life has been related to insulin resistance [36]
More recently, alterations of adipogenesis, as well as disruption of the adiposity gene expression and leptin synthesis have been observed [37].

EDCs are also able to stimulate the glucocorticoid receptor (GR) and as glucocorticoid signaling is central to adipocyte differentiation, they are able to promote adipogenesis in the 3T3-L1 Cell Line through the activation of the GR, thus leading to obesity [38].

A key role seems to play adiponectin, an adipocytespecific hormone that increases insulin sensitivity and reduces tissue inflammation. As a consequence, any factor that suppresses adiponectin release could lead to insulin resistance and increased susceptibility to obesity and its associated diseases [31].

Furthermore, it has been shown that 2,3,7,8-tetrachlorodibenzo-p-dioxin (TCDD) induces complex changes in enzymes of oxidative stress in adipocytes and may cause insulin resistance $[39,40]$.

\section{Conclusions}

Obesity has a clearly remarkable impact on health related quality of life. However, the determinants of obesity pandemic are many and yet poorly defined.

There is emerging evidence that exposure to environmental chemicals is associated with obesity and related diseases, even if a cause-effect relationship between the two events has still to be demonstrated. As a consequence, further studies need to be carried out (i) to perform updated exposure measures for hazard and risk estimation, (ii) to define the assessment of the potential hazards emanating from these chemicals, and (iii) as no risk may be justified when the health of humans is involved, to find alternative and better quality materials replacing those at this moment present on the market.

\section{Abbreviations}

BPA: Bisphenol A; DDE: dichlorodiphenyl-dichloroethylene; EDC: endocrine disrupting chemicals; IGF - 1: insuline-like growth factor - 1; GH: growth hormone; GR: glucocorticoid receptor; PBDEs: polybrominated diphenyl ethers; PCBs: polychlorinated biphenyls; POPs: persistent organic pollutants; PPARs: peroxisome proliferator-activated receptors; TBT: tributyltin; TCDD: 2,3,7,8-tetrachlorodibenzo-p-dioxin

\section{Author details}

'Division of Neonatology, Perrino Hospital, Brindisi, Italy. ${ }^{2}$ Clinical Physiology Institute, National Research Council of Italy (IFC-CNR), Lecce Section, Italy. ${ }^{3}$ Division of Pediatrics, Perrino Hospital, Brindisi, Italy. ${ }^{4}$ Department of Paediatrics, University of Modena and Reggio Emilia, Modena, Italy.

Received: 4 January 2010

Accepted: 22 January 2010 Published: 22 January 2010

\section{References}

1. Kipping RR, Jago R, Lawlor DA: Obesity in children. Part 1: Epidemiology, measurement, risk factors, and screening. BMJ 2008, 337:a1824.

2. James WP: The epidemiology of obesity: the size of the problem. I Intern Med 2008, 263:336-52. 
3. Ford ES, Mokdad AH: Epidemiology of obesity in the Western Hemisphere. J Clin Endocrinol Metab 2008, 93(11 Suppl 1):S1-8.

4. Shaw J: Epidemiology of childhood type 2 diabetes and obesity. Pediatr Diabetes 2007, 8(Suppl 9):7-15.

5. Caprio S: Insulin resistance in childhood obesity. Pediatr Endocrinol Metab 2002, 15(Suppl 1):487-92.

6. Grün F: Blumberg B. Endocrine disrupters as obesogens. Mol Cell Endocrinol 2009, 304:19-29.

7. Newbold RR, Padilla-Banks E, Snyder RJ, Jefferson WN: Perinatal exposure to environmental estrogens and the development of obesity. Mol Nutr Food Res 2007, 51:912-7.

8. Heindel JJ, vom Saal FS: Role of nutrition and environmental endocrine disrupting chemicals during the perinatal period on the aetiology of obesity. Mol Cell Endocrinol 2009, 304:90-6.

9. Schell LM, Gallo MV, Ravenscroft J: Environmental influences on human growth and development: Historical review and case study of contemporary influences. Ann Hum Biol 2009, 36:459-477.

10. Foster WG, Agzarian J: Toward less confusing terminology in endocrine disruptor research. J Toxicol Environ Health B Crit Rev 2008, 11:152-61.

11. Tabb MM, Blumberg B: New modes of action for endocrine-disrupting chemicals. Mol Endocrinol 2006, 20:475-82

12. Newbold RR, Padilla-Banks E, Jefferson WN, Heindel JJ: Effects of endocrine disruptors on obesity. Int J Androl 2008, 31:201-8

13. Newbold RR, Padilla-Banks E, Jefferson WN: Environmental estrogens and obesity. Mol Cell Endocrinol 2009, 304:84-9.

14. Yoshinari K, Sato T, Okino N, Sugatani J, Miwa M: Expression and induction of cytochromes p450 in rat white adipose tissue. J Pharmacol Exp Ther 2004, 311:147-54.

15. Heindel JJ, vom Saal FS: Role of nutrition and environmental endocrine disrupting chemicals during the perinatal period on the aetiology of obesity. Mol Cell Endocrinol 2009, 304:90-6.

16. Elobeid MA, Allison DB: Putative environmental-endocrine disruptors and obesity: a review. Curr Opin Endocrinol Diabetes Obes 2008, 15:403-8.

17. Merrill M, Baston DS, Denison MS, Birnbaum LS, Pomp D, Threadgill DW Mouse breast cancer model-dependent changes in metabolic syndromeassociated phenotypes caused by maternal dioxin exposure and dietary fat. Am J Physiol Endocrinol Metab 2009, 296:E203-10.

18. Gluckman PD, Lillycrop KA, Vickers MH, Pleasants AB, Phillips ES, Beedle AS, Burdge GC, Hanson MA: Metabolic plasticity during mammalian development is directionally dependent on early nutritional status. Proc Natl Acad Sci USA 2007, 104:12796-800.

19. Hanson MA, Gluckman PD: Developmental origins of health and disease: new insights. Basic Clin Pharmacol Toxicol 2008, 102:90-3.

20. Tilg H, Moschen AR: Adipocytokines: mediators linking adipose tissue, inflammation and immunity. Nature Reviews Immunology 2006, 6:772-783.

21. Margetic S, Gazzola C, Pegg GG, Hill RA: Leptin: a review of its peripheral actions and interactions. Int J Obes Relat Metab Disord 2002, 26:1407-33.

22. Sperling MA: Disorders of energy balance. Pediatric endocrinology textbook 3 2008, 788-796.

23. Díez JJ, Iglesias $P$ : The role of the novel adipocyte-derived hormone adiponectin in human disease. Eur J Endocrinol 2003, 148:293-300.

24. Rondinone CM: Adipocyte-derived hormones, cytokines, and mediators. Endocrine 2006, 29:81-90

25. Shah A, Mehta N, Reilly MP: Adipose inflammation, insulin resistance, and cardiovascular disease. J Parenter Enteral Nutr 2008, 32:638-644.

26. Ghosh D, Griswold J, Erman M, Pangborn : Structural basis for androgen specificity and oestrogen synthesis in human aromatase. Nature 2009, 457:219-23.

27. Siviero-Miachon AA, Spinola-Castro AM, Guerra-Junior G: Adiposity in childhood cancer survivors: insights into obesity physiopathology. Arq Bras Endocrinol Metab 2009, 53:190-200.

28. Prokesch A, Hackl H, Hakim-Weber R, Bornstein SR, Trajanoski Z: Novel insights into adipogenesis from omics data. Curr Med Chem 2009, 16:2952-64.

29. Sakurai K, Kawazuma M, Adachi T, Harigaya T, Saito Y, Hashimoto N, Mori C Bisphenol A affects glucose transport in mouse 3T3-F442A adipocytes. Br J Pharmacol 2004, 141:209-14.

30. Iyawaki J, Sakayama K, Kato H, Yamamoto H, Masuno H: Perinatal and postnatal exposure to bisphenol a increases adipose tissue mass and serum cholesterol level in mice. J Atheroscler Thromb 2007, 14:245-52.
31. Hugo ER, Brandebourg TD, Woo JG, Loftus J, Alexander JW, BenJonathan N: Bisphenol A at environmentally relevant doses inhibits adiponectin release from human adipose tissue explants and adipocytes. Environ Health Perspect 2008, 116:1642-7.

32. Hatch EE, Nelson JW, Qureshi MM, Weinberg J, Moore LL, Singer M, Webster TF: Association of urinary phthalate metabolite concentrations with body mass index and waist circumference: a cross-sectional study of NHANES data, 1999-2002. Environ Health 2008, 3:7-27.

33. Desvergne B, Feige JN, Casals-Casas C: PPAR-mediated activity of phthalates: A link to the obesity epidemic?. Mol Cell Endocrinol 2009, 304:43-8.

34. Inadera $\mathrm{H}$, Shimomura $\mathrm{A}$ : Environmental chemical tributyltin augments adipocyte differentiation. Toxicol Lett 2005, 159:226-34.

35. Karmaus W, Osuch JR, Eneli I, Mudd LM, Zhang J, Mikucki D, Haan P, Davis S: Maternal levels of dichlorodiphenyl-dichloroethylene (DDE) may increase weight and body mass index in adult female offspring. Occup Environ Med 2009, 66:143-9.

36. Latini G, Wittassek $M$, Del Vecchio A, Presta G, De Felice C, Angerer J: Lactational Exposure to Phthalates in Southern Italy. Environ Int 2009, 35:236-239.

37. Phrakonkham $P$, Viengchareun $S$, Belloir $C$, Lombès $M$, Artur $Y$, CanivencLavier MC: Dietary xenoestrogens differentially impair 3T3-L1 preadipocyte differentiation and persistently affect leptin synthesis. $J$ Steroid Biochem Mol Biol 2008, 110:95-103.

38. Sargis RM, Johnson DN, Choudhury RA, Brady MJ: Environmental Endocrine Disruptors Promote Adipogenesis in the 3T3-L1 Cell Line through Glucocorticoid Receptor Activation. Obesity (Silver Spring) 2009.

39. Kern PA, Fishman RB, Song W, Brown AD, Fonseca V: The effect of 2,3,7,8tetrachlorodibenzo-p-dioxin (TCDD) on oxidative enzymes in adypocites and liver. Toxicology 2002, 171:117-25

40. Cranmer M, Louie S, Kennedy RH, Kern PA, Fonseca VA: Exposure to 2,3,7,8-tetrachlorodibenzo-p-dioxin (TCDD) is associated with hyperinsulinemia and insulin resistance. Toxicol Sci 2000, 56:431-6.

doi:10.1186/1824-7288-36-8

Cite this article as: Latini et al:: Toxic environment and obesity pandemia: Is there a relationship?. Italian Journal of Pediatrics 2010 36:8.

\section{Publish with Bio Med Central and every scientist can read your work free of charge}

"BioMed Central will be the most significant development for disseminating the results of biomedical research in our lifetime. "

Sir Paul Nurse, Cancer Research UK

Your research papers will be:

- available free of charge to the entire biomedical community

- peer reviewed and published immediately upon acceptance

- cited in PubMed and archived on PubMed Central

- yours - you keep the copyright 